Finanse, Rynki Finansowe, Ubezpieczenia nr 4/2016 (82), cz. 1

\title{
A Cooperative Company in Agriculture: Feasibility Analysis of a Start-up project
}

\author{
Maurizio Lanfranchi, Carlo Giannetto, \\ Angelina DePascale, Yulia Khachatryan*
}

\begin{abstract}
Purpose - The research objective is to analyse the economic and financial dynamics of an agricultural cooperative in a start-up phase.

Design/methodology/approach - The research starts from an analysis of the alternative forms of product marketing, which is necessary to identify the operational field of the company that is going to be set up, and focuses on raising those financial resources which are necessary to allow the start and the ordinary course of the business. The financing of cooperative companies has always been a remarkably relevant issue in the management of this type of business. Indeed, the technical and legal features of these companies have limited the access to possible financing sources and, in particular, to venture capital acquisitions.

Originality/value - Throughout this work, we tried to suggest the financial instruments best suited to meeting the needs of an agriculture company in a start-up phase and, in this respect, in an economic situation like the present one, assisted finance may represent a useful instrument. However, the opportunities that it offers at different levels are often unknown or not perceived for their complexity and for the lack of clear and homogeneous information.
\end{abstract}

Keywords: cooperative, agriculture, start-up, financial instruments, corporate model

\section{Introduction}

For many years, the prevailing opinion was that business and a cooperative were two completely different phenomena, almost opposing ones. In recent times, instead, the economic crisis that has consequently questioned the capitalist economic model, which is excessively profit-driven, has made possible a reduction of the distances between the two concepts. The recent economic and financial crisis and the consequent recession have definitely confirmed the failure of liberism, namely the market's ability to be self-regulating. They have disproved the assumption according to which the market, finance, economy and business have to be completely disconnected from any ethical constraints, and have pointed out that, alongside those businesses whose only purpose is profit maximization, there should be others that, on the contrary, aim at achieving social utility. Today, more than ever, the

\footnotetext{
* Maurizio Lanfranchi, Department of Economics, University of Messina, e-mail: mlanfranchi@unime.it; Carlo Giannetto, Department of Economics, University of Messina, e-mail: mlanfranchi@unime.it; Angelina DePascale, Department of Economics, University of Messina, e-mail: mlanfranchi@unime.it; Yulia Khachatryan, University of Kemerovo (Russia).
} 
economy needs counter cyclical trends and these may be provided only by promoting a culture of cooperation. The idea of a business aiming at creating economic wealth should not make us believe that this is its final goal. Indeed, the philosophical tradition, from which an economy derives, reminds us that wealth is an instrument for pursuing our happiness and, in this contest; a key role is that of the common good, which is the goal of government activity and of science administration. This means that the new challenge for the economy is to prove that it is possible to do business even when pursuing objectives of social utility. In a period of history such as ours, characterised by the disappearance of certainties in the world of work, the idea of a cooperative may be a credible and winning proposal and could be an opportunity for youths to access the labour world (Wheeler, Sillanpaa 1997). Today, cooperation is a fundamental reality for the Italian economy, including both large dominant companies in the distribution, construction, insurance, finance and agri-food sector and for small businesses spread over the whole national territory and operating in the widest range of markets. In view of the remarkable importance that a cooperative company has acquired in the course of time and in the light of the specific features that distinguish it from the other forms of business, as well as for organizational reasons, it is regarded as the corporate form best suited for creating a business project that may be realized by youths in the primary sector (D'Amico et al. 2013). In particular, it is mainly geared to stimulate the local economy by promoting and enhancing the products of the area, as well as being a work opportunity for the three authors of the initiative (Bellows, Nasr 2010).

\section{Cooperatives in agriculture}

The cooperative system was born in the period of the Industrial Revolution, with the shift from a craft making production system to an industrial one, and it is rooted in the experiences of collective needs, diseconomies, difficulties and problems linked to differences among social classes. In Italy, the cooperative phenomenon had some difficulties in establishing itself and the first experiences proved to be even negative. Indeed, many companies set up as a cooperative, after the first periods of experimentation, were reproducing the production and trade systems which were typical of speculative activities and, therefore, in contrast with the founding spirit of cooperation, that is, precisely, mutuality. Only at the beginning of the twentieth century, due to the boost given by the Socialist movement and the Catholic associationism, the cooperative model started to assert itself in Italy, also with the establishment of the first consortia aimed at grouping this type of company. Therefore, in cooperatives, economic activity is exercised with the aim of meeting a particular need of the shareholders, to whom it is addressed in order to enable the achievement of a common interest, which is different from the remuneration of the carried out investment (Bernstein, Peter 1998). The mutual goal and consequently the advantage for the shareholders themselves may be achieved only through an exchange between them and the company. The company will have to equip itself with an appropriate organization for supplying goods, services or work 
opportunities at more advantageous conditions than those available in the market (Dale et al. 1987). The shareholders will have to make a contract with the company and therefore to exploit benefits, both because otherwise they could not obtain any mutualistic benefits and because their inertia would nullify the managerial efficiency of the company, which, in the long term, would be no longer able to ensure identical favourable conditions (Bryson 2004). The distinction between prevalently mutual cooperatives and other cooperatives does not pose a problem of the qualification of the present case, but is justified only on the level of the tax benefits that the law recognizes to the former ones. Prevalently, mutual cooperatives will have to include in their statutes:

- the prohibition of redistributing dividends at rates greater than the maximum interest of postal savings bonds, increased by two and half percentage points as compared to the actually paid-up capital,

- the prohibition of remunerating the financial instruments offered in subscription to the cooperative shareholders at a rate of two percentage points above the maximum limit provided for dividends,

- the prohibition of distributing reserves among cooperative shareholders,

- the obligation to devolve, in the event of the company's dissolution, the entire company's assets, only deducting the share capital and the possibly measured dividends to the mutual funds for the promotion and development of the cooperative.

Moreover, cooperative companies are characterized by the fact that they have a variable capital, which is not therefore determined on the basis of an established amount. This implies that the admittance of new shareholders does not involve a modification of the deed of implementation, even though an admission procedure, carried out with a resolution by the directors, is provided for them, since, in order to join this company, they must satisfy the requirements which are previously established in the deed of incorporation (Frame 2003). However, the capital fulfils the same functions that it has in gainful capital companies (Clarkson 1995). This feature is linked to the open door principle, namely, in these companies the membership structure cannot be closed to the entry of new shareholders, and the corporate base appears to be extremely fractional. Cooperatives are endowed with a perfect patrimonial autonomy, meaning that only the company with its assets deals with social obligations (Măzăreanu 2013). In order to ensure the presence on the market of cooperatives capable of realizing the social function that they have, the supervisory authority has the power to dissolve the company that does not, or is no longer able to pursue the mutual purpose. In this perspective, both the hypothesis of the non-fulfilment of management actions for two consecutive years, as a confirmation of the impossibility to pursue the mutual purpose, and that of the non-submission of the financial statement are shared (Sgroi et al. 2015). To conclude, it is possible to state that the founding values of the cooperative are able to build both a high share capital and a relational capital that favour the creation of trust-based relationships. This statement is justified by the central position that the worker member occupies in 
his/her participation in the economic and production system and in the values of mutuality and reciprocity that characterize the cooperative organization (Crescimanno et al. 2014).

\section{Strengths and weaknesses of a cooperative venture in agriculture}

At this stage, it appears appropriate to highlight the strengths and weaknesses that characterize cooperatives.

As regards to the former, we can distinguish:

- flexible management, that can be noted both from an organizational and from an operational point of view,

- management dynamism, defined as the speed of reorganizing the company's strategic choices,

- establishment and exploitation of the synergies that are developed among cooperatives operating in the same sector,

- mutualism, as an instrument which is able to strengthen the sharing within the company,

- deep-rooted attachment,

- democratic principle, which allows a greater and better control of the company,

- inexpensiveness, as a means to guarantee the business' durability in the long term,

- participation as an element aimed at involving and strengthening the activities of coordination, guidance and control of the company,

- group work, as a natural operating mode in an extremely motivating and involving environment,

- creation of stable and long-lasting trust-based relationships.

On the contrary, passing on the analysis of the weaknesses, it is possible to identify:

- an undercapitalisation, caused by the possibility given by the legislator himself to build companies even composed by only three members,

- slower decision-making processes, due to the needs for transparency, that characterize this type of company,

- a mainly medium-small structure that limits their growth trend,

- a low propensity to the accumulation of resources and to capital growth,

- an excessive fragmentation of the corporate base due to the open door principle,

- a risk of resting on the tax and financial advantages that the law itself recognizes to these companies.

As it can be easily noticed, the cooperative company is characterised at a greater rate by positive elements and indeed, these factors have contributed to the affirmation of this company in the market and have been a crucial element in the choices made by young entrepreneurs (Beierle 2002; Paraschiv 2012). 


\section{Research objectives and discussion}

The research objective is to analyse the economic and financial dynamics of an agricultural cooperative in the start-up phase. The new company that will have to be built has the following denomination: "Sicilia Verde limited liability Cooperative". It aims to offer a wide range of purely local and natural products coming from farms on the territory, previously selected by the company's founders. These founders, during the various production phases will have to comply with certain rules established in detail within a protocol which had been previously drawn up by the promoters of the initiative. The business, becoming a carrier of a stable and direct relationship between producer and consumer, is capable of eliminating possible intermediaries in the exchanges, consequently reducing the final price of goods and even managing to bring the consumer closer to his or her land, by increasing his/her knowledge of local products and producers. Therefore, the company places itself as an alternative form of marketing agri-food products, being part of a wider category, denominated by the scientific literature on the subject "short supply chain". The research starts from an analysis of the alternative forms of product marketing, which is necessary to identify the operational field of the company that is going to be set up, and focuses on the raising of those financial resources which are necessary to allow the start and the ordinary course of the business (Bodemann, Olaru 2014).

\section{Procurement of Financial Instruments}

The financing of cooperative companies has always been a remarkably relevant issue in the management of this type of business. Indeed, the technical and legal features of these companies have limited the access to possible financing sources and, in particular, to venture capital acquisitions (Eden, Ackermann 1998). Alongside these issues, we should not forget the particular economic and financial situation that not only Italy, but the whole world is currently experiencing, which is generating not only a serious economic crisis, but also in terms of trust among operators. For these reasons, it proves to be increasingly difficult for the already existing businesses to survive in the market in these conditions, and for the newly built ones to succeed in finding the financial resources which would enable them to make the necessary investments to start their activity. At this stage, it is essential to quote the example of a cooperative called "Sicilia Verde limited liability Cooperative". Even in this company there are some problems, which are relatively common to all small-sized businesses, that, among other things, are those which mainly operate in Italy. For this reason, the founding members of the "Sicilia Verde limited liability Cooperative" company, in terms of raising finance, have decided to avail themselves with the competences of the employees of a local popular bank. This choice is linked both to the modus operandi that is generally typical of all BCC, particularly attentive to the needs of local communities and deeply rooted in the territory in which they are settled, and to the organisational structure that, more 
specifically, distinguishes the local popular bank, It is mainly composed of young graduates from the University of Messina, who are strongly motivated and firmly believe in what they do. Being a local bank, and thus having a good knowledge of the reality in which it operates, the popular bank manages to establish close and long-lasting relationships both with families and with the businesses operating in that area (Lanfranchi et al. 2014). This is clearly an advantage, since it enables to reduce information asymmetry and the related problems, such as adverse selection, moral hazard and credit rationing which, if present, would limit the possibilities of local development. In other terms, "the cooperative form, especially if with a tax base relatively concentrated in a limited geographical area and generally socio-economically homogeneous, enables credit institutions to mitigate the risk of adverse selection and moral hazards in the granting of credits, not being affected by the unequal distribution of information that can more easily paralyze the adoption of other larger banks with a capitalistic tax base, for which the entry into circumscribed markets may be hindered by the customers' bad knowledge of creditworthiness. In addition, the local bank, and especially the one with a cooperative structure, thanks to its good knowledge of the territory in which it operates, manages to guarantee a better selection of customers and allows reducing the costs linked to the assessment of creditworthiness and to the management of credit lines. It manages to create a relation of reciprocity (relationship banking) with the business. It is also able to assist the employer, since it does not confine itself to providing credits, but can also carry out assessments on the company as a whole and evaluate the feasibility of the projects. In this way, the newly set up company will be able to benefit from a series of collateral services which will not be limited to simple credit granting, but which will range from the support for new entrepreneurs, to the assessment of the company as a whole and to the evaluation of the feasibility of projects. Therefore, the bank will have an active role within the company, and will be assisting it in its different stages, as well as providing consultancy activities. In this respect, it would be useful to analyse the project started precisely by the popular bank entitled "Finanzio Impresa". It was created with the aim of stimulating and promoting youth entrepreneurship, providing instruments aimed at promoting the birth of new companies and to encourage young people to stay in their regions, inventing their own work and creating some for others. With this initiative the bank confirms its role of a partner of young people and of their future by providing practical answers to real needs. Not only in terms of credit support, but of a real "accompaniment" along the path that young entrepreneurs decide to undertake. The product is technically an unsecured-debt, created in order to cover the needs of an initial investment, both material and immaterial ones. The mortgage for the start-up involves a pre-amortisation, up to 12 months, which consists of the possibility to pay only interests for the first year (in order to trigger off the activity), a maximum duration of 60 months (besides the pre-amortisation), and a maximum amount of 100,000 Euros. The bank will provide funding by a variable rate of $4 \%$ and the guarantees for its provision will be issued by Medio Credito Centrale, through the Central Fund of Guarantee, so that the company will be free from the grant of any other additional 
guarantee. The activation of this guarantee practically enables the bank to have a zero risk, since, in the case of the insolvency of the firm, this will be compensated by the Central Fund of Guarantee and in case of the possible exhaustion of its funds, directly by the State. Naturally, the choice of granting the guarantee by Medio Credito Centrale will be linked to the bank itself after a detailed analysis of the business project and of the business plan, including a forecast balance of at least three years. The guarantee will not be certainly granted if equity (which must result to have already been paid on the date of the disbursement of the loan) is inferior to $25 \%$ of the amount of the investment programme. The guarantee is explicit, unconditional and irrevocable; it is also direct, as meaning that it refers to a single exposure. Youths will be practically supported in their crucial steps. This will permit the monitoring of their evolution in the first delicate months of activity, thus contributing also to mitigating the credit risk. Another institution which the new entrepreneurs may decide to rely on is IRCAC (Regional Institute for Cooperative Credit), set up with the regional law n.12 of February 7th 1963. In the aim of promoting, increasing and strengthening cooperation in Sicily, it grants aid to Sicilian firms in the form of financing facilities for productive investments, for promotional and marketing activities, for ensuring the necessary financial backing of the project, and for the capitalisation of the company. Moreover, it ensures the granting of contributions and interests on bank loans and on leasing transactions granted by societies which are partners of the bank and intervenes in the favour of all the SMEs operating in Sicily by granting aid provided by special law provisions. The financial benefits granted by IRCAC may be used by the cooperatives which have their headquarters in the area of the Sicilian Region and operate in all production sectors, except for those firms operating in the fishing and aquaculture fields, in the primary production of agricultural products and in the coal sector. The financial benefits of IRCAC may be provided within the limits established for "de minimis" aid by Regulation (CE) n.1998/2006. The total amount of "de minimis" aid granted to a firm, in the form of a direct subsidy, cannot exceed 200,000 Euros over three financial years. For the facilitations granted by the IRCAC, the amount of the aid is the gross grant equivalent of the funding updated at the moment of the grant. This ceiling cap will be automatically adjusted to the variations possibly recorded to the aforesaid European regulation on "de minimis" aid. Also in this case, the company will be able to avail itself of the advisory service offered by the bank, related both to the analysis of the economic and financial situation of the company and to the guidance in the choice of funding. Taking a closer look at the products offered by the bank, it is possible to find some which are appropriate for the "Sicilia Verde limited liability Cooperative". The type of credit which seems to be more suitable for meeting the needs of the company being formed is the medium-term one, facilitated for productive investments and for promotional and marketing activities. It is granted for the establishment of new firms, as well as for the extension, modernization, restructuring, reconversion, diversification and rationalization of already existing installations and for the funding of promotional and marketing activity designed to the internationalization of the Sicilian businesses. More specifically, the expenses that may be object to provisions are: 
1. Planning and management of works, studies of economic and financial feasibility and of environmental impact assessment (closely linked to the proposed programme of investments), charges for construction permits and statutory inspections, up to a maximum value of $3 \%$ of the overall admissible investment.

2. Acquisition of patents and of exploitation licenses, initial franchising shares, consultancy to obtain quality or environmental certifications, computer programmes.

3. Purchase of the immovable property necessary for carrying out the company's activity.

4. Building and assimilated works for the creation and/or adjustment of estate property intended for the company's activity and for the alignment with the current regulations.

5. Purchase of plants, machinery and equipment.

6. Purchase of furniture.

7. Purchase of vehicles strictly necessary for the exercise of the activity object of provisions and at its exclusive service.

8. Investments for the participation in national and foreign trade fairs of international relevance with reference to the purchase of the exhibition area and of standard equipment, to the costs of possible insurance premiums and of advertising material in the official catalogue of the event; investments for the realization of advertising and promotional campaigns abroad through the acquisition of advertising spaces in the printed press, television, informative signs or the design of promotional and advertising material in a foreign language in the form of brochures, videos, CDs and others;

9. Investments for the acquisition of studies necessary for the introduction of a new product or of an existing product in a new geographical market. Specialised consultancies carried out by professionals by consulting companies, including tax, legal, contractual, economic and financial and design assessment may be financed. The above fees are allowed, net of VAT and at an appropriate level compared to the type of initiative and to the market conditions. Only those expenses that, on the basis of the relative invoice date or of other supporting document for expenditure, appear to have been incurred after the date when the application for funding was submitted, may be considered eligible. The product characteristics can be summarized as follows:

a) durability: up to 15 years, including a period of pre-amortisation not exceeding twenty-four months;

b) rate: $30 \%$ ( $40 \%$ in the case of industrial plants) of the reference Rate agreed by the European Commission;

c) intervention limit: not exceeding 70\% (60\% in case of industrial plants) of the value of eligible investment. Coverage of the remaining 30\% charged to the beneficiary cooperative by means of:

- increase of the share capital for the corresponding amount,

- through non-interest bearing loan by shareholders throughout the funding, 
- with any other resource deemed suitable and which is included in the financial plan produced by the bank;

d) operating procedures: application on a special form, supported by the aforementioned documentation.

It appears to be of the utmost importance also that a communication and information transfer system, being as clear and transparent as possible, is created with banks and guarantee consortia. Therefore, the company will have the task of organising structured information, bearing the relative costs, since the assessments carried out by credit institutions concerning credit supply and creditworthiness will also depend on this. Reducing the concealment of information will be one of the key priorities for all the firms that will look for the right approach with credit institutions and with guarantee consortia.

Especially in the specific case when the company applying for funding is at its start-up phase, the attention will be focused to a greater extent on the business idea, and it will be positively assessed only if it is able to generate future cash flows sufficient for capital and interests repayment. It is therefore necessary that banks and credit consortia have a series of data which enable to correctly assess the firm and the investments that it has put in place. The business plan will have a key-role in the project assessment, since through it, not only the cooperative will be able to have a clear overview of the situation and to consequently take the most appropriate decisions, but even financiers will be able to identify the transaction's potential, the sustainability of the project and returns in terms of generated wealth. In this way, the basis for a clear and open relationship between entrepreneurs, financers and guarantors will be launched.

\section{Conclusions}

From the survey that was carried out it was possible to infer that the most suitable corporate model for the implementation of the analysed project is that of the cooperative, considering its particular features and for organizational reasons. Throughout this work we tried to suggest the most appropriate financial instrument to meet the needs of a society at its start-up phase and, in this respect, in an economic situation like the present one, assisted finance may represent a useful instrument. However, the opportunities that it offers at different levels are often unknown or not perceived for their complexity and for the lack of clear and homogeneous information. For this reason, it would be of the utmost importance that institutions or category associations started specific projects aimed at providing additional services to businesses, for example regarding information on the calls or financial subsidy measures issued at any level, from the European Union to Chambers of Commerce. This will be aimed at providing both an informative and consulting service that enables the firm to adjust its activity to the demanded requirements, in order to achieve a certain goal. The various research that was carried out shows that the business idea contains all the characteristics that can enable the development of the Messina region. 


\section{References}

Beierle T.C. (2002). The Quality of Stakeholder-based Decision. Risk Analysis, 22 (4), 739-749.

Bellows A.C.E., Nasr J. (2010). On the past and the future of the urban agriculture movement: reflections in tribute to Jac Smit. Journal of Agriculture, Food Systems, and Community Development.

Bernstein P.L. (1998). Against the Gods: The Remarkable Story of Risk. New York, NY: John Wiley \& Sons.

Bodemann M., Olaru, M. (2014). Responsibility to customers in the context of public value management - A German case study. Amfiteatru Economic, 16 (35), 171-186.

Bryson J.M. (2004). What to do when stakeholders matter: A Guide to stakeholder identification and analysis techniques. Public Management Review, 6 (1), 21-53.

Clarkson M.B.E., (1995). A Stakeholder Framework for Analyzing and Evaluating Corporate Social Performance. The Academy of Management Review, 20 (1), 92-117.

Cooper D.F., Chapman C.B. (1987). Risk Analysis for Large Projects: Models, Methods, and Cases. Chichester: John Wiley.

Crescimanno M., Galati A., Bal T. (2014). The role of the economic crisis on the competitiveness of the agri-food sector in the main Mediterranean countries. Agricultural Economics (Czech Republic), 60 (2), 49-64.

D’Amico M., Coppola A., Chinnici G., Di Vita G., Pappalardo G. (2013). Agricultural systems in the European Union: An analysis of regional differences. New Medit, 12 (4), 28-34.

Eden C., Ackermann F. (1998). Making Strategy. The Journey of Strategic Management. London: Sage Publications.

Frame J.D. (2003). Managing risk in organizations. A guide for managers. Washington: Jossey-Bass.

Lanfranchi M., Giannetto C., De Pascale A. (2014). The role of nature-based tourism in generating multiplying effects for socio economic development of rural areas. Quality - Access to Success, 15 (140), 96-100.

Măzăreanu V.-P. (2013). Considerations on risk in supply chain management information systems implementation. Amfiteatru Economic, 15 (33), 128-139.

Paraschiv D.M., Nemoianu E.L., Langa C.A., Szabó T. (2012). Eco-innovation, responsible leadership and organizational change for corporate sustainability. Amfiteatru Economic, 14 (32), 404-419.

Sgroi F., Candela M., Di Trapani A.M., Foderà M., Squatrito R., Testa R., Tudisca S. (2015). Economic and financial comparison between organic and conventional farming in Sicilian lemon orchards. Sustainability (Switzerland), 7 (1), 947-961.

Wheeler D., Sillanpaa M. (1997). The Stakeholder Corporation: a blueprint for maximising stakeholder value. London: Pitman Publishing.

\section{SPÓLDZIELNIA W ROLNICTWIE: ANALIZA WYKONALNOŚCI PROJEKTU START-UP}

Streszczenie: $\mathrm{Cel}$ - Celem badania jest analiza dynamiki gospodarczej i finansowej spółdzielni rolniczej w fazie początkowej.

Metodologia - Badanie rozpoczyna się od analizy alternatywnych form produktów marketingowych, które są niezbędne do określenia pola operacyjnego firmy. Finansowanie przedsiębiorstw spółdzielczych zawsze było niezwykle istotną kwestią w zarządzanie tego typu działalności. Istotnie, parametry techniczne i prawne tych firm mają ograniczone możliwości do źródeł finansowania.

Oryginalność/wartość - W całej tej pracy, staraliśmy się zaproponować instrumenty finansowe, które najlepiej odpowiadają na potrzeby spółdzielni rolnej w fazie początkowej.

Słowa kluczowe: spółdzielnia rolna, instrumenty finansowe, model korporacyjny

\section{Citation}

Lanfranchi M., Giannetto C., DePascale A., Khachatryan Y. (2016). A Cooperative Company in Agriculture: Feasibility Analysis of a Start-up project. Finanse, Rynki Finansowe, Ubezpieczenia, 4 (82/1), 113-122. DOI: 10. 18276/frfu.2016.4.82/1-09. 